\title{
EFEKTIVITAS PENERAPAN PEMBELAJARAN BERBASIS MULTIPEL REPRESENTASI TERHADAP PENGUASAAN KONSEP MATERI GAYA SENTRAL PADA MAHASISWA PENDIDIKAN FISIKA.
}

\author{
Tri Isti Hartini ${ }^{12^{*}}$, Liliasari ${ }^{1}$, Agus Setiawan ${ }^{1}$, and Taufik Ramlan Ramalis ${ }^{1}$ \\ ${ }^{I}$ Departemen Pendidikan IPA, Sekolah Pascasarjana, Universitas Pendidikan Indonesia, \\ Jl. Dr.SetiabudhiNo. 229, Bandung 40154, Indonesia \\ ${ }^{2}$ Program Studi Pendidikan Fisika- FKIP, Universitas Muhammadiyah Prof. Dr. Hamka, \\ Jl. Tanah Merdeka, Kp. Rambutan, Ciracas, Jakarta Timur, Indonesia \\ *E-mail: istifisika@gmail.com
}

\begin{abstract}
Abstrak : Penelitian ini bertujuan untuk mengetahui penguasaan konsep dan efektivitas penerapan pembelajaran berbasis multipel representasi terhadap penguasaan konsep materi gaya sentral pada mahasiswa pendidikan fisika. Subjek penelitian ini adalah mahasiswa semester 3 yang berjumlah 32 orang. Rancangan penelitian yang dilakukan yaitu pre experimental dalam bentuk one shot case study. Instrumen pengumpulan data dalam penelitian ini adalah tes hasil belajar penguasaan konsep gaya sentral mahasiswa yang sesuai dengan indikator pemahaman konsep menggunakan Anderson and Krathwohl Bloom's Taxonomy Revised. Data dianalisis melalui teknik analisis deksriptif tentang penguasaan konsep gaya sentral mahasiswa dengan menggunakan kriteria penguasaan konsep dan efektivitas pembelajaran menggunakan multipel representasi (MR). Hasil penelitian ini didapatkan nilai rata-rata untuk penguasaan konsep gaya sentral, dari seluruh indikator yaitu menjelaskan dan mencontohkan, mengklasifikasi, menganalisis, membandingkan serta mengevaluasi, diperoleh bahwa indikator dengan penguasaan konsep tertinggi terdapat pada indikator mengklasifikasikan dengan kategori sangat baik, sedangkan penguasaan konsep terendah terletak pada indikator membandingkan, dengan kategori cukup. Dengan demikian dapat disimpulkan bahwa penerapan pembelajaran mekanika berbasis multipel representasi efektif diterapkan pada materi gaya sentral mahasiswa pendidikan fisika.
\end{abstract}

Kata Kunci: Efektivitas, penguasaan konsep, gaya sentral, multipel representasi.

\section{PENDAHULUAN}

Learning Outcome dalam mata kuliah mekanika ini, mahasiswa mampu: memahami konsep dan prinsip mekanika dalam bentuk formalisme yang lebih umum, memiliki wawasan yang luas dalam menganalisis permasalahan mekanika partikel, kinematika partikel, System koordinat polar, Dinamika partikel, Gerak harmonik, Gaya sentral, Kerangka acuan tidak inersial (non inersial), Sistem Partikel, Rotasi Benda Tegar, Mekanika Lagrange, mengenal konsep-konsep dan prinsip-prinsip mekanika klasik dalam perumusan biasa maupun Langrange dan Hamilton, menjelaskan gejala-gejala tertentu berlandaskan hukum-hukum 
mekanika, serta dapat menyelesaikan masalah-masalah sederhana terkait. Materi konsep dasar mekanika, meliputi; gerak gaya sentral, gerak gaya sentral sebagai benda sistem dua benda, persamaan gerak dalam medan potensial sentral, orbit medan gaya sentral dan potensial efektif, hukum Keppler pada gerak planet, gaya sentral dan energi potensial, merumuskan konsep atau prinsip yang terdapat dalam hukum newton tentang gravitasi.

Gaya belajar merupakan cara siswa menyerap informasi, misalnya ada siswa yang lebih mudah menyerap dengan pembelajaran verbal, namun ada siswa yang lebih mudah dengan pembelajaran gambar atau matematis. Menghadapi gaya belajar yang demikian maka diperlukan suatu pendekatan pembelajaran yang dapat menyampaikan materi secara multiple representasi. Gaya belajar dapat digolongkan menjadi tiga macam gaya yaitu visual, auditorial dan kinestetik. Dari ketiga gaya belajar ini ada individu yang cenderung pada salah satu gaya, dan ada juga yang cenderung semua gaya belajar. Jika strategi mengajar guru sama dengan gaya belajar siswa, maka tidak ada pelajaran yang sulit . Multipel representasi dan multimedia dapat mendukung pembelajaran dalam banyak cara yang berbeda. Belajar dengan multipel presentasi lebih efektif dalam membangun model mental siswa dan memahami konsep di bandingkan dengan pembelajaran konvensional. Salah satu alternatif pendekatan pembelajaran yang sangat baik diterapkan dalam pembelajaran mata kuliah mekanika adalah pendekatan pembelajaran berbasis multipel representasi. Representasi adalah suatu konfigurasi (bentuk atau susunan) yang dapat menggambarkan, mewakili atau melambangkan sesuatu dalam suatu cara, maka pendekatan multiple representasi adalah suatu cara untuk menyatakan suatu konsep melalui berbagai cara, bentuk atau format yang berbeda baik itu verbal, gambar, grafik dan matematis. Tahap-tahap pendekatan multipel representasi akan dilaksanakan tiap pertemuan mulai dari orientasi fisis pada siswa, penyajian model fenomena berupa demonstrasi, penanaman konsep melalui LKM berbasis multipel representasi, penyajian aplikasi konsep dan pemberian tindak lanjut belajar. Mahasiswa dituntut untuk dapat membuktikan kegunaan multipel representasi, dapat membantunya mengidentifikasi dan mendeskripsikan suatu masalah secara lebih utuh dan menyelesaikannya dengan pemahaman, nalar dan argumentasi yang kokoh.

\section{METODE PENELITIAN}

Penelitian ini dilaksanakan disebuah PTS di Jakarta, dimulai pada bulan Oktober sampai Nopember 2017. Jenis penelitian ini adalah pre-experimental dengan rancangan bentuk one shot case study [14]. Dalam penelitian ini tahap pelaksanaan penelitian meliputi perlakuan dengan menerapkan pembelajaran fisika berbasis multipel representasi $(\mathrm{X})$ dan hasil setelah perlakuan $(\mathrm{O})$, dimana hasil setelah perlakuan yang diteliti adalah hasil belajar penguasaan konsep gaya sentral. Subjek pada penelitian ini adalah mahasiswa semester 3 tahun ajaran 2017/2018. Jumlah mahasiswa adalah sebanyak 32 orang. Instrumen pengumpul data pada 
penelitian ini menggunakan tes penguasaan konsep gaya sentral mahasiswa dengan lima pertanyaan sesuai indikator penguasaan konsep menurut Anderson and Krathwohl Bloom's Taxonomy Revised. Teknik analisis data dalam penelitian ini dilakukan dengan analisis deskriptif melalui kriteria penguasaan konsep dan efektivitas pembelajaran.

\section{HASIL DAN PEMBAHASAN}

Banyak penelitian menunjukkan bahwa multipel representasi dapat memiliki manfaat besar untuk students' learning. Namun beberapa research juga memperingatkan bahwa multipel representasi mungkin gagal untuk meningkatkan belajar siswa, jika tidak digunakan dengan cara yang 'benar'[9]. Representasi dalam fisika memiliki dua aspek, fisik dan konseptual yang mendasar yang dapat berinteraksi untuk mendukung atau menghambat penalaran dan pemecahan masalah [7] . Data yang terkumpul dalam penelitian ini berupa rekapitulasi nilai penguasaan konsep gaya sentral mahasiswa, yang diperoleh setelah penerapan pembelajaran materi gaya sentral berbasis multipel representasi. Faktor penyebab terbatasnya atau kesulitan siswa dalam memahami suatu konsep fisika adalah ketidakmampuan siswa menggunakan multipel representasi dalam memahami konsep fisika [9]. Untuk mendeskripsikan penguasaan konsep dan efektivitas pembelajaran siswa dianalisis berdasarkan nilai pada tiap indikator penguasaan konsep gaya sentral. Hasil penelitian yang diperoleh pada penguasaan konsep hasil belajar untuk tiap indikator dapat ditunjukkan pada Tabel 1 .

Tabel 1. Penguasaan konsep gaya sentral mahasiswa

\begin{tabular}{lllll}
\hline No & $\begin{array}{c}\text { Kegiatan } \\
\text { penguasaan } \\
\text { konsep }\end{array}$ & $\begin{array}{c}\text { Rata-rata } \\
\text { nilai }(\%)\end{array}$ & $\begin{array}{c}\text { Kategori } \\
\text { penguasaan }\end{array}$ & $\begin{array}{c}\text { Efektivitas } \\
\text { pembelajaran }\end{array}$ \\
\hline 1 & $\begin{array}{l}\text { Menjelaskan dan } \\
\text { mencontohkan }\end{array}$ & 80,50 & Baik & Efektif \\
2 & Mengklasifikasi & 86,65 & Sangat baik & $\begin{array}{l}\text { Sangat } \\
\text { Efektif }\end{array}$ \\
3 & Menganalisis & 76,74 & Baik & Efektif \\
4 & Membandingkan & 66,55 & Kurang baik & Kurang \\
& Mengevaluasi & 78,80 & Baik & Efektif \\
5 & Efektif \\
Rata-rata & 77,85 & Baik & Efektif \\
\hline
\end{tabular}

Pada Tabel 1, Mahasiswa sebagian besar mampu menguasai konsep pada topik gaya sentral. Hal tersebut ditunjukkan dengan hasil kemampuan mahasiswa dalam menjelaskan, mencontohkan, mengklasifikasi, menganalisis, dan mengevaluasi. Penguasaan konsep gaya sentral dalam mengklasifikasi konsep gaya sentral memperoleh rata-rata nilai yang tinggi dan kemampuan membandingkan 
memperoleh rata-rata nilai yang rendah. Dengan demikian diperoleh penguasaan konsep untuk seluruh indikator kategori pembelajaran yang baik dan efektif.

Sub konsep pada materi gaya sentral meliputi gerak relatif partikel, hukum Keppler, potensial gravitasi, energi pusat orbit dan gaya konservatif. Untuk dapat menjelaskan pencapaian tiap indikator dan sesuai sub konsep, maka akan ditampilkan diagram batang [11], presentase jumlah penguasaan konsep pada tiap indikator berdasarkan sub konsep pada gaya sentral dapat dilihat pada Gambar 1 .

\section{Hasil Ketercapaian Indikator sesuai Sub Konsep Gaya Sentral}

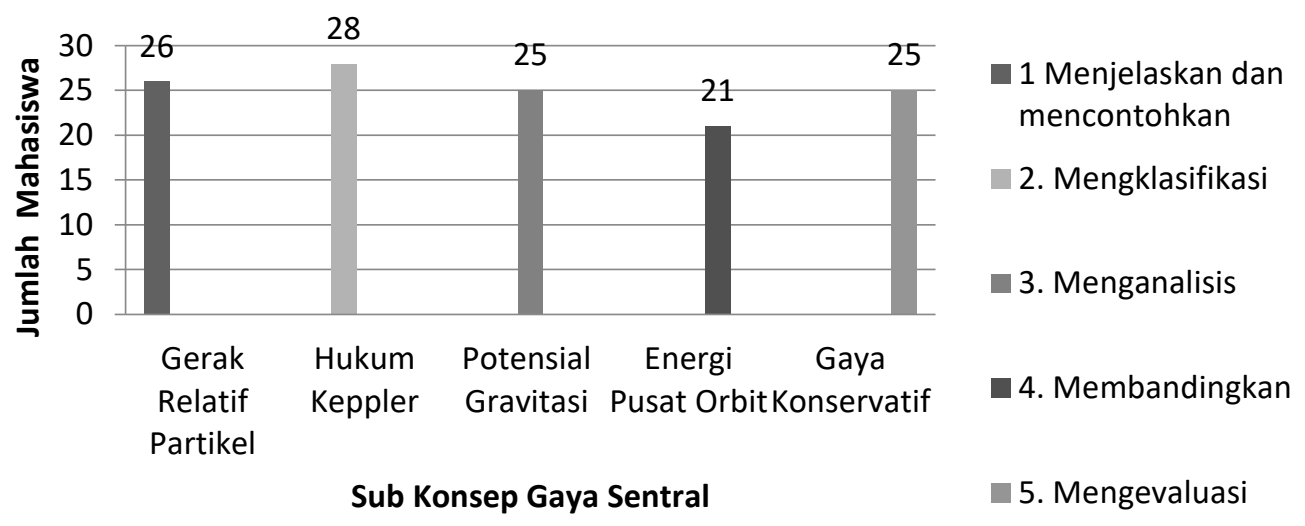

Gambar 1. Grafik Hasil Ketercapaian Indikator Sesuai Sub Konsep Gaya Sentral

Berdasarkan pada gambar 1 terlihat bahwa jumlah penguasaan konsep mahasiswa tertinggi terdapat pada indikator mengklasifikasi yang mencapai 28 mahasiswa yang telah berhasil mengklasifikasi hukum Keppler dari jumlah 32 mahasiswa, sedangkan jumlah indikator terendah mencapai 21 mahasiswa mampu membandingkan penguasaan konsep energi pusat orbit. Sesuai gambar 1 mengindentifikasikan bahwa penguasaan konsep pada hukum Keppler lebih dikuasai mahasiswa, selanjutnya pada penguasaan konsep pada gerak relatif partikel, gaya konservatif, potensial gravitasi dan energi pusat orbit.

\section{PENUTUP}

Hasil analisa data dan pembahasan mengenai penguasaan konsep gaya sentral pada mahasiswa semester 3 didapatkan bahwa penguasaan konsep rata-rata mahasiswa berbasis multipel representasi mencapai kategori baik, meskipun masih ada indikator yang rendah pencapaiannya. Kemudian ditinjau dari aspek lima indikator penguasaan konsep gaya sentral pada mahasiswa bahwa penguasaan konsep tertinggi terdapat pada indikator mengklasifikasikan dengan persentase sebesar $86,65 \%$, sedangkan penguasaan konsep mahasiswa terendah terletak pada indikator membandingkan yaitu sebesar $66,55 \%$, maka pembelajaran matakuliah mekanika pada konsep gaya sentral melalui pendekatan pembelajaran berbasis 
multipel representasi efektif diterapkan pada materi mekanika topik yang lain untuk mahasiswa pendidikan fisika semester 3. Berdasarkan kesimpulan dari hasil penelitian, maka penulis menyarankan bahwa penerapan pembelajaran materi gaya sentral berbasis multipel representasi dapat digunakan sebagai salah satu alternatif pendekatan pembelajaran pada materi lain yang berbasiskan penanaman konsep dan diharapkan kepada peneliti lain dapat memberikan pendekatan pembelajaran mekanika berbasis multipel representasi yang lebih bervariasi.

\section{DAFTAR PUSTAKA}

Ainsworth, S (1999). The functions of multiple representations. ESRC Centre for Research in Development, Instruction and Training, Computers \& Education. 33 (1999). 131-152.

Anderson, Lorin W., Krathwohl DR., Airasian, PW. (2001). A Taxonomy For Learning,Teaching, and Assesing. Longman. New York.

Bahri, Samsul. 2012. Penggunaan Multiple Representasi dan Argumentasi Ilmiah dalam Pembelajaran Fisika. Jurnal Pendidikan Serambi Ilmu, 12(1), 46-50.

Chatib, munif. (2014). Orangtuanya Manusia: Melejitkan Potensi dan Kecerdasan dengan MenghargaiFitrah Setiap Anak. Bandung: PT Mizan Pustaka.

De Porter, Bobbi, dan Hernacki, Mik. (2007). Quantum Learning.Diterjemahkan oleh Alwiyah Adurrahman. Bandung: Kaifa PT.Mizan Pustaka.

Fowles. R. Grant, (2006), Analytical Mechanics. Thomson Brooks/Cole 10 Davis Drive Belmont, CA 94002 USA

Gire E, (2014), Arrows as anchors: An analysis of the material features of electric field vector arrows

Goldin, G.A. (2002). Representation in mathematical learning and problem solving. Dalam L.D English (Ed). Hand book of international research in mathematics education (IRME). New Jersey: Lawrence Erlbaum Associates.

Gunel, M., Hand, B., \& Gunduz, S. (2006). Comparing Student Understanding of Quantum Physics When Embedding Multimodal Representations into Two Different Writing Formats: Presentation Format Versus Summary Report Format. www.interscience.wiley.com. (diakses tanggal 13 Februari 2016).

Rau, A.M.\&Percival, G.M. (2017). How to make 'more' better? Principles for effective use of multiple representations to enhance students' learning about fractions. Accepted: 23 February 2017.

Kadir (2017). Statistik Terapan Konsep, Contoh Dan Analisis Data Dengan Proram SPPS/Lisrel Dalam Penelitian. Buku Beta. Jogya - Sleman.

Rendiyansah, et al. (2013). Pengembangan Modul Pembelajaran Fisika Berbasis Multi Representasi Pada Materi Pokok Suhu Dan Kalor. Jurnal Pembelajaran Fisika. Universitas Lampung. Lampung. (diakses tanggal 11 Februari 2016). 
Suhandi dan Wibowo F.C. 2012. Pendekatan Multirepresentasi dalam Pembelajaran Usaha Energi dan Dampak terhadap Pemahaman Konsep Mahasiswa. Jurnal Pendidikan Fisika Indonesia. UPI - Bandung. 8, 1-7.

Suryabrata, S. (2002). Metodologi Penelitian. Jakarta: PT. Raja Grafindo Persada. Sunyono, (2015). Supporting Students in Learning with Multiple Representation to Improve Student Mental Models on Atomic Structure Concepts. Science Education International. 26(2), 104-125.

Wilson, L.O. (2016). Anderson and Krathwohl Bloom's Taxonomy Revised: Understanding the new version of bloom's taxonomy. Articel course handbook diakses pada hari selasa tanggal 5 uni 2018 dari http://www4.uwsp.edu/education/lwilson/curric/newtaxonomy.htm. 